\title{
'Better late than never': the interplay between green technology and age for firm growth
}

\author{
Riccardo Leoncini • Alberto Marzucchi • \\ Sandro Montresor • Francesco Rentocchini • \\ Ugo Rizzo
}

Accepted: 30 June 2017 / Published online: 6 November 2017

C) The Author(s) 2017. This article is an open access publication growth is greater than that of non-green technologies. However, this result does not apply to struggling and rapidly growing firms. With fast-growing (above the median) firms, age moderates the growth effect of green technologies. Inconsistent with the extant literature, this moderation effect is positive: firm experience appears important for the growth benefits of green technologies, possibly relative to the complexity of their management.

Keywords Green technology · Firm growth · Age · Quantile fixed effects
Electronic supplementary material The online version of this article (https://doi.org/10.1007/s11187-017-9939-6) contains supplementary material, which is available to authorized users.

R. Leoncini

University of Bologna, Bologna, Italy

e-mail: riccardo.leoncini@unibo.it

\section{R. Leoncini}

Freiburg Institute for Advanced Studies (FRIAS), University of Freiburg, Freiburg im Breisgau, Germany

R. Leoncini

IRCrES-CNR, Milan, Italy

A. Marzucchi $(\bowtie)$

SPRU, Science Policy Research Unit, University of Sussex, Brighton, UK

e-mail: a.marzucchi@susssex.ac.uk

\author{
S. Montresor \\ Faculty of Economics and Law, Kore University of Enna, \\ Cittadella Universitaria, 94100 Enna, EN, Italy \\ e-mail: sandro.montresor@unikore.it \\ F. Rentocchini \\ Department of Economics, Management and Quantitative \\ Methods, University of Milan, Milan, Italy \\ e-mail: francesco.rentocchini@unimi.it \\ F. Rentocchini \\ Southampton Business School, University of Southampton, \\ Southampton, UK \\ U. Rizzo \\ Department of Economics and Management, University of \\ Ferrara, Ferrara, Italy \\ e-mail: ugo.rizzo@unife.it
}


JEL Classification $\mathrm{L} 26 \cdot \mathrm{O} 33 \cdot \mathrm{Q} 55$

\section{Introduction}

Following the 'Porter hypothesis' and the debate over 'whether it pays to be green', studies have shown that by complying with environmental regulations, adopting sustainable practices and eco-innovating, firms can become more competitive (Porter and Van der Linde 1995; Ambec and Lanoie 2008; Ambec et al. 2013) if not even more profitable (Horváthová 2010; Ghisetti and Rennings 2014). However, the impact of green technologies on firm growth has been minimally investigated, especially given the abundant literature on 'standard' innovation as a growth driver (Sutton 1998; Bottazzi and Secchi 2006; Lotti et al. 2009; Coad and Holz 2012). ${ }^{1}$ Supportive evidence has been mainly obtained by examining the relationship between eco-innovations and firm growth through the lens of the technology-jobs nexus, usually in a non-longitudinal setting (e.g. Gagliardi et al. 2016; Rennings and Zwick 2002). However, with few exceptions, these analyses do not address the 'growth premium' attached to green technologies vis-à-vis the non-green ones, nor do they pay attention to the inner complexity and dynamics of the phenomenon.

The present paper aims to close this gap by addressing two research questions. We first draw on the idea from the field of industrial organisation that the growth effect of technology exploitation varies with the pace at which a firm grows, given that growth opportunities and threats change at different growth rates (Coad and Rao 2006). Hence, we investigate whether the growth outcome of eco-innovations depends on the firm's pace of growth and on whether the firm is struggling or rapidly growing. To address this research question, we rely on a novel methodological approach: a quantile regression analysis (e.g. Coad and Rao 2008; Coad and Rao 2010; Coad et al. 2013) performed by using a fixed effects estimation technique (Canay 2011). This technique captures the potentially heterogeneous effects of green (and non-green) technologies on firm growth across different growth rates, while controlling for unobserved heterogeneity.

\footnotetext{
${ }^{1}$ This issue is related to, but different from the relatively more studied topic of the (mainly policy) drivers of 'green growth', for which see, among the others, Hallegatte et al. (2012).
}

The second research question examines whether the firm's age influences the growth impact of green technologies. Again, we are informed by the industrial organisation literature (e.g. Barba Navaretti et al. 2014; Distante et al. 2014): we consider age-dependent mechanisms that characterise the firm's capacity to exploit innovation (Coad et al. 2016) and add to them specific ones related to eco-innovations. By studying the knowledge complexity implications of eco-innovations (e.g. in terms of risk and financing) and the higher need for technology experience to grasp it (Carrillo-Hermosilla et al. 2010), we investigate whether age moderates how the firm's growth benefits from green technologies.

These two original research questions are addressed by relying on a novel longitudinal dataset comprising 5498 Italian manufacturing firms studied over the period of 2000-2008. In our econometric analysis, the impact of green and non-green patents on the firm's growth, as measured by employment growth, is moderated by age. Our main findings are as follows. First, green technologies have a greater impact on firm growth than nongreen ones, except in the case of struggling and rapidly growing firms. Second, the firm's age positively moderates the growth effect of green technologies for fastgrowing (above the median) firms. We discuss the management and policy implications for both scenarios.

The remainder of the paper is structured as follows. Section 2 reviews relevant background literature. Section 3 presents the empirical application. Section 4 illustrates the results. Section 5 presents the conclusion.

\section{Background literature and research questions}

Surprisingly, despite the importance given to green and sustainable growth in the current policy debate, the role of eco-innovations in driving firm growth has scarcely been investigated. Although firm growth can be measured through different variables at the micro-level, like job creation, assets and sales growth (Coad 2009), our contribution to the nascent literature on the growth effects of green technologies focuses on employment. While we empirically justify our choice in Section 3.3, it is also motivated by our attempt to complement a recent stream of literature about the effects of eco-innovations on the dynamics of firm employment. These studies investigate the possible positive (e.g. driven by product demand or higher staff requirements for operating environmental technologies) and negative (e.g. displacement 
and substitution) employment effects of different types of eco-innovations (Rennings and Zwick 2002; Rennings et al. 2004; Licht and Peters 2013; Horbach and Rennings 2013). However, they generally rely on cross-sectional, self-reported survey data, often using binary variables for capturing employment growth (Rennings and Zwick 2002; Rennings et al. 2004; Horbach and Rennings 2013) and/or focusing only on eco-innovators (Rennings and Zwick 2002; Rennings et al. 2004), thus preventing the distinction between occasional and persistent effects.

More relevant to our analysis is the patent-based study carried out in Italy (2001-2008) by Gagliardi et al. (2016), showing that eco-innovator firms have more employment growth than their non-green counterparts. Similarly, Colombelli et al. (2015) studied patents of more than 400,000 firms in Germany, France, Italy, Spain and Sweden over the period of 2002-2011 and found that eco-innovation capabilities drive sales growth more than 'generic' ones.

On the strength of these previous contributions, we argue that, despite their higher costs (Gagliardi et al. 2016), new green technologies could provide firms with 'extra returns' compared to non-green technologies. These extra returns can be exploited (e.g. re-invested) and, as we posit, yield an employment growth premium to eco-innovators. This argument finds support in three different research streams. At the outset, by extending the debate on Schumpeterian innovation regimes to the green realm (Malerba 2005; Oltra and Saint Jean 2009), we argue that eco-innovators could make a more effective 'creative accumulation' of knowledge (i.e. Schumpeter Mark II) than standard ones and translate economic returns into higher growth opportunities. Given the irreversibility of complying with environmental regulations, investing in green-specific assets and acquiring internal/external green knowledge (Oltra and Saint Jean 2009; Mazzanti and Rizzo 2017) and environmental technologies have actually been found to lead to more persistent (eco-) innovation practices and outcomes than standard technologies, with greater opportunities of increasing returns (see Sàez-Martínez et al. 2016; Chassagnon and Haned 2015).

A growth premium from green vs. non-green technologies is also supported by the literature on the joint improvements of environmental and economic/financial performances of firms (i.e. their 'win-win' strategies). The green-specific mechanisms that increase firm revenues (e.g. green differentiation of products, access to green demand segments and sale of environmental control technologies) and reduce costs (e.g. material and energy efficiency, and recycling initiatives) (see Ambec and Lanoie 2008) provide eco-innovators with improved financial indicators (e.g. Misani and Pogutz 2015), greater profits (Ghisetti and Rennings 2014) and, in general, extra economic returns to be turned into higher growth.

Finally, the regulations and policy actions on which eco-innovations depend (the so-called regulatory push/ pull effect) also represent an 'extra' driver of growth. 'Polluting' firms at the end of the value chain are legally forced to improve their environmental performances and, in so doing, 'induce' an additional element of 'derived demand' in the upstream producers of green technologies that fuels the latter's growth (Colombelli et al. 2015; Ghisetti and Quatraro 2013).

In summary, the extant literature seems to imply a growth effect of green technologies vs. non-green ones, which can depend on two scarcely analysed aspects: (i) the pace at which firms grow and (ii) the firm age.

The pace aspect has been confirmed through the use of quantile regressions for standard innovations. Coad et al. (2016), for example, showed that only the fastest-growing firms benefit from standard innovation in terms of employment growth, while this return is actually negative for the slowest-growing ones. In general, fast-growing firms have been shown to have crucial advantages in the 'job creation argument' (for a review see Almus 2002). First, they are generally smaller, and thus more prone to commercialising their innovations, and younger, and accordingly more in need of investing in the knowledge they miss at the beginning of their businesses. Second, they often operate in technology-intensive sectors and are thus endowed with a larger knowledge base, qualified human capital and technological skills and experience. They also usually have a limited liability legal form, thus showing greater incentives for riskier but also more rewarding innovations. Finally, their close connection to suppliers, customers and competitors enables them to benefit from an open innovation approach.

As these aspects do not vary by the nature of the relevant technologies and given the absence of specific literature on green technologies, we maintain that the distinction between rapidly and slowly growing firms could be a relevant factor for ecoinnovations too. Although in a non-quantile 
framework, but rather in a dynamic parametric estimation of Gibrat's law (Gibrat 1931, 2003), this is confirmed by Colombelli et al. (2015). They find that the growth differential between green and generic technologies is actually greater for firms growing at more than 'the average' rate. We interpret this in light of the 'induced' innovation, which is the 'derived demand' from environmental regulations that fuels green sectors.

With regard to the second aspect of our analysis, in the industrial organisational literature, age has a twofold effect on growth. On the one hand, it is (along with size) an important determinant of a firm's growth potential, with a large (although not yet conclusive) body of evidence favouring younger firms (Haltiwanger et al. 2013; Lawless 2014). On the other hand, age (along with other characteristics) is a crucial moderating factor of the impact of innovative activity on firms' growth (Audretsch et al. 2014) and on employment growth, in particular (Coad et al. 2016).

However, the role of age in the relationship between green technologies and growth has received little emphasis. A sort of 'sin of youth' seems to emerge from the literature on '(eco-)sustainable entrepreneurship' (Dean and McMullen 2007), in which the comparative analyses of start-ups (young firms) vs. incumbent (old) firms have been very rare, so far, and specific to some sectors (e.g. green electricity and microfinance) (Hockerts and Wustenhagen, Hockerts and Wüstenhagen 2010). While 'emerging green Davids' usually show higher environmental commitment and attractiveness to sustainable consumers, they often fail to translate their niche market potential into a broad mass market, mainly because of the competition from incumbent 'greening Goliaths', through their 'inner' form of corporate sustainable entrepreneurship (e.g. Bird et al. 2002; Stenzel and Frenzel 2008).

Other and more general age-related insights emerge from environmental and eco-innovation studies, all suggesting a greater growth potential of mature eco-innovators. First, an older firm can be expected to have an advantage in terms of learning experience against the multidimensionality and complexity that characterises green knowledge (Carrillo-Hermosilla et al. 2010) and new green product development projects (Tsai 2012). Second, younger firms may be more averse to the growth exploitation of green technologies, as these are often in the early stage of their life cycles and thus marked by greater uncertainty than non-green ones (Consoli et al. 2016). Similarly, young firms could be disfavoured in benefiting from policy instruments for the adoption of green-tech-such as new practices of green public procurement (Parikka-Alhola 2008) - as these are still marked by uncertainty and require experience in managing demand-pull policy. Third, given the hard collaterisation and information signalling of green investment projects, older firms could be expected to have better access to financing (Schneider and Veugelers 2010) and be better prepared to cope with the higher cost of eco-innovations without crowding out other growth-driving investments (Hall et al. 2016). Last, but not the least, older firms may have an advantage in strengthening their available resources to increase their economic green returns (e.g. through economies of scale) as well as in forming alliances to tap into external resources (e.g. through reputation and market position) (e.g. Cainelli et al. 2015). Similarly, firm maturity could be beneficial for searching, absorbing and transforming external knowledge (Franco et al. 2014) towards adopting the open eco-innovation mode (Ghisetti et al. 2015), particularly when accessing new and foreign markets (e.g. Autio et al. 2000; D’Agostino 2015). ${ }^{2}$

In light of the above aspects, our study attempts to address the firm growth potential of green vs. non-green technologies, by providing new empirical evidence for two original research questions: (1) To what extent does the association between green technologies and firm growth vary along the conditional distribution of growth rates? (2) What is the role that a firm's age plays in the relationship between green technologies and growth?

\section{Empirical application}

\subsection{Data}

The empirical analysis is based on a dataset that has been obtained by combining three different sources (see

\footnotetext{
$\overline{2}$ The arguments about the growth potential of mature (young) companies that we have just presented refer to green technologies in general terms (i.e. without distinguishing specific environmental targets or technological realms). In the absence of theoretical backing and/or prior empirical findings on the existence of differences for different green technological realms, we distinguish between green and nongreen technologies only, without focusing on specific green technologies.
} 
Online Appendix A1 for details): (i) the ASIA database of the Italian National Statistical Office (ISTAT); (ii) the Bureau van Dijk AIDA database; (iii) and the Worldwide Patent Statistical Database (PATSTAT).

By restricting our sample to manufacturing companies (Section D of NACE Rev. 1.1) that filed at least one patent application in the period of 1977-2008 and because of the availability of the other relevant data sources (see Online Appendix A1), we ended up with an unbalanced panel comprising 5498 firms observed over the period of 2000-2008. The focus on patenting firms allows us to minimise unobserved heterogeneity in terms of innovative capabilities across firms. Given that the objective here is to investigate the growth premium, if any, offered by green vs. non-green innovations and the moderating effect of age in the relationship between innovative activity and growth, our implications will be valid for innovative firms only. ${ }^{3}$

\subsection{Methodology}

To address our research questions (see Section 2), we investigate the following relationship:

$$
\begin{aligned}
\text { Growth }_{i t}= & \alpha+\beta_{1}{\text { Pat } \text { Green }_{i, t-1}} \\
& +\beta_{2} \text { Pat Nongreen }_{i, t-1}+\beta_{3} \text { Age }_{i, t-1} \\
& +\beta_{4}(\text { Pat Green X Age })_{i, t-1} \\
& +\beta_{5}(\text { Pat Nongreen X Age })_{i, t-1} \\
& +\mathbf{z}_{i, t-1}^{\prime} \gamma+\delta_{t}+\mu_{i}+\varepsilon_{i t}
\end{aligned}
$$

where $\delta_{t}$ indicates a series of time dummies; $\mathbf{z}_{i, t-1}^{\prime}$ is a vector of firm-specific control variables; $\mu_{i}$ denotes the unobserved firm-specific effects; and $\varepsilon_{i t}$ is the error term.

Building upon previous empirical works on the relationship between growth and innovation, and given our focal interest in the role of the pace at which firms grow, we employ a quantile regression approach (Coad and Rao 2008; Kesidou and Demirel 2012). As is well

\footnotetext{
${ }^{3}$ Table A1 in the Online Appendix reports the difference in 1-year employment growth, employment and age between our sample and the overall population of Italian companies (source: ASIA-ISTAT). We test whether the means for the variables above are statistically different between the two groups. In line with the approach of Gagliardi et al. (2016), who employed similar data, firms in our sample are older and bigger, while there is no significant difference in terms of employment growth.
}

known, this approach allows for a richer characterisation of the data: it disentangles the relationships between our independent variables and firm growth at different quantiles of the distribution of the growth rates, rather than at the conditional mean only. Further, as is normally the case when investigating firm growth (Buchinsky 1998; Bottazzi and Secchi 2003), quantile analysis is preferable over standard least squares for different reasons linked to the distribution of the growth rates in our sample (see Online Appendix A2).

Most of the applied literature adopting a quantile regression approach stems from cross-sectional settings, and for this reason, controlling for problems of endogeneity arising from unobserved heterogeneity has been difficult. Conversely, we follow recent developments in a stream of the applied econometrics literature that has attempted to overcome this major limitation (Koenker 2004; Galvao 2011; Canay 2011). Specifically, we implement the procedure suggested by Canay (2011), who developed a method to estimate fixed effects quantile regressions for panel data. The solution proposed consists of a two-step estimator. In the first step, we estimate our previous equation (1) as a standard linear panel regression model via the within estimator (Wooldridge 2010). From this model, we obtain the predicted value depurated from the unobserved heterogeneity component:

$\hat{y}_{i t}=$ Growth $_{i t}-\hat{\mu}_{i}$

where $\hat{\mu}_{i}=E\left[\right.$ Growth $\left._{i t}-\widehat{\text { Grow } t h_{i t}}\right]$ is an estimate of the unobserved heterogeneity term. In the second step, a standard quantile regression model is implemented in which the transformed dependent variable above $\left(\hat{y}_{i t}\right)$ is regressed on our relevant independent variables (Koenker and Hallock 2001).

\subsection{Variables}

Our dependent variable is the growth rate of employees $\left(\right.$ Growth $\left._{i t}\right)$, calculated as the difference between the logarithm of firm $i$ 's employees in year $t$ and the logarithm of employees in year $t-1$ (Coad and Rao 2006; Coad 2010) (see Online Appendix A3 for details). In addition to theoretical reasons (see Section 2), this choice has also empirical motivations. Unlike other measures (Delmar et al. 2003) such as sales growth, employment growth can capture growth performance in recently constituted firms (Clarysse et al. 2011). 
We have three main independent variables: (i) Pat Green $_{i, t-1}$, which is the logarithm of the stock (at time $t-1$ ) of environmentally friendly technologies (plus 1 ), filed by firm $i$; (ii) Pat Nongreen $_{i, t-1}$ is the logarithm of the stock of non-environmentally friendly technologies (plus 1); (iii) $\mathrm{Age}_{i, t-1}$ which measures the (log transformed) age of company $i$ at time $t-1$, with the difference between the current and its constitution date.

Despite its limitations as an innovation proxy, patent data has been used by most of the recent research on ecoinnovations because they are, on the one hand, more widely available and more informative than $R \& D$ about their environmental nature and, on the other hand, a more robust indicator than questionnaire-based measures (Arundel and Kemp 2009; Berrone et al. 2013). For the identification of 'green patents' in particular, we have relied on Marin and Lotti (2016) (see Online Appendix A3). Both green and non-green technological variables are defined as stocks, rather than flows (see Online Appendix A3 for details). We do so because we expect a firm's rate of growth to be affected by the knowledge cumulated over time and not only by its variation added in the recent and/or current period (Bloom and Van Reenen 2002; Hall et al. 2005). This also helps reduce, at least partially, the possible confounding effect of the persistency in technological leadership (Denicolò, 2001) on firm growth, which cannot be addressed by controlling for unobserved heterogeneity (Peters 2009). ${ }^{4}$

We control for a set of variables that are often included in growth rate regression models: (i) investments in tangible (Inv Tang ${ }_{i, t-1}$ ) and intangible (Inv Intang $\operatorname{Iit}_{i, 1}$ ) assets (at time $t-1$ ), recognised by the literature to have an important role in 'accounting' for the firm's capacity to grow (Hall 1987); (ii) a measurement of size in terms of number of employees of firm $i$ at time $t-1\left(\mathrm{Emp}_{, t-1}\right)$, used to retain the implications of the Gibrat's law (e.g. Evans 1987; Hall 1987; Calvo 2006); (iii) an HerfindahlHirschman index of industry concentration (Herfindahl index $_{j t}$ ), which has been often found to play a relevant role with respect to firms' performance (Kaniovski and Peneder 2008) (see Online Appendix A3 for details).

Finally, we include a set of eight dummy variables to control for year effects. Table 1 shows the variables included in the analysis and their sources.

\footnotetext{
$\overline{4}$ The empirical literature does not point to unambiguous evidence on the relevance of persistence in technological innovation, especially when it comes to major innovation or patents (Raymond et al. 2010). In these cases, partial support for the presence of persistence emerges when considering top innovators (Geroski et al. 1997; Cefis 2003).
}

Table 1 Variables' description

\begin{tabular}{|c|c|c|}
\hline Variable name & Description & Source \\
\hline Growth $_{i t}$ & $\begin{array}{l}\text { Growth of employees of firm } \\
\quad i \text { in year } t \\
\quad\left(\operatorname{lnsize}_{i t}-\operatorname{lnsize}_{i t-1}\right)\end{array}$ & ASIA Istat \\
\hline Pat Green $_{i t-1}$ & $\begin{array}{l}\text { Stock of green patents of } \\
\text { firm } i \text { in year } t-1(\log \\
\text { transformed) }\end{array}$ & PATSTAT \\
\hline Pat Nongreen $_{i t-1}$ & $\begin{array}{l}\text { Stock of non-green patents of } \\
\text { firm } i \text { in year } t-1(\log \\
\text { transformed })\end{array}$ & PATSTAT \\
\hline $\mathrm{Age}_{i t-1}$ & $\begin{array}{l}\text { Number of years since } \\
\text { constitution of firm } i \text { in } \\
\text { year } t-1 \text { (log } \\
\text { transformed) }\end{array}$ & ASIA Istat \\
\hline $\mathrm{Emp}_{i t-1}$ & $\begin{array}{l}\text { Number of employees of } \\
\text { firm } i \text { in year } t-1(\log \\
\text { transformed) }\end{array}$ & ASIA Istat \\
\hline Inv $\operatorname{Tang}_{i t-1}$ & $\begin{array}{l}\text { Investment in physical } \\
\text { capital of firm } i \text { in year } \\
t-1 \text { (log transformed) }\end{array}$ & AIDA BvD \\
\hline Inv Intang ${ }_{i t-1}$ & $\begin{array}{l}\text { Investment in intangible } \\
\text { capital of firm } i \text { in year } \\
t-1 \text { (log transformed) }\end{array}$ & AIDA BvD \\
\hline Herfindahl index $_{j t}$ & $\begin{array}{l}\text { Herfindahl-Hirschman index } \\
\text { of industry concentration } \\
\text { for industry } j \text { at time } t\end{array}$ & AIDA BvD \\
\hline
\end{tabular}

Descriptive statistics of the variables employed in the empirical exercise are reported in Table 2. Table 3 reports the bivariate correlations of the variables considered in the analysis. No indication of significant multi-collinearity among the independent variables was found (i.e. the variance inflation factor ranges from 1.02 to 2.62 , well below the threshold level of 5).

\section{Results}

The results of the quantile fixed effect estimations are presented in Table 4, which shows the baseline model, and in Table 5, which incorporates the role of the firm's age as a moderating factor in the relationship between environmental (and non-environmental) patents and firm's growth. $^{5}$

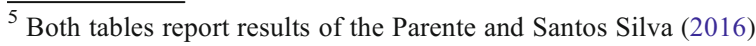
test to determine whether intra-industry correlation affects the standard errors in our estimates. Results show that, apart from the 50th percentile, all other percentiles (10th, 25th, 75th and 90th) are affected by intra-cluster correlation. Results reported in the tables therefore use cluster-robust standard errors at industry level (NACE rev. 1.12 digit codes).
} 
Table 2 Descriptive statistics for the pooled sample $(n=30,670)$

\begin{tabular}{lccccc}
\hline Variable & Mean & Median & SD & Min. & Max. \\
\hline Growth & -0.006 & -0.024 & 0.225 & -4.336 & 5.945 \\
Pat Green & 0.143 & 0.000 & 1.223 & 0.000 & 0.000 \\
Pat Nongreen & 2.123 & 0.614 & 15.027 & 1.000 & 961.138 \\
Age & 23.949 & 24 & 13.622 & 0.080 & 141 \\
Emp & 171.510 & 53 & 675.774 & 0.001 & $3,115,048$ \\
Inv Tang & 2854.694 & 297.096 & $149,183.460$ & 0.001 & $1,617,583$ \\
Inv Intang & 1031.039 & 48.698 & 0.047 & 0.001 & 0.909 \\
Herfindahl index & 0.014 & 0.003 & & &
\end{tabular}

All values are reported before log transformation

Starting with the controls, as expected (e.g. Coad and Holz 2012), both tangible and intangible investments significantly drive firm growth. As for size, smaller companies show greater growth opportunities and capacities, in agreement with the entrepreneurship literature (Acs and Audretsch 2006). An increase in market concentration (Herfindahl index) seems to favour firm growth, although the effect is significant-and positive- only at the 50th and 90th percentiles. This result resonates well with the characterisation of the 'Schumpeter Mark II' pattern of innovation (Malerba and Orsenigo 1995) - marked by an oligopolistic context with high technological opportunities and appropriability - which the former literature actually identified in a section of the Italian national system of innovation (Malerba 1993), and that here appears to be represented by fast-growing companies.

As far as firm's age is concerned, the results of the standard literature on the growth advantages of newly created companies (Coad et al. 2013; Barba Navaretti et al. 2014) appeared reversed across all quantiles in Table 4: unexpectedly, older companies grow more than younger ones. This result can be only be partially explained by the specificity of our quantile methodology. Most likely, its explanation lies in the characteristics of our sample. Our sample consists of innovationoriented manufacturing firms operating in a national context, where new-born firms face structural difficulties in taking off and surviving (Audretsch et al. 1999), and where established incumbents usually obtain the most radical innovation outcomes (Malerba 1993). The importance of banks in financing innovation (Benfratello et al. 2008) also plays a key role in the Italian context, and mature firms are more capable (e.g. by reputation) of developing borrowing relationships for their innovations (Gregory et al. 2005; Hartarska and Gonzalez-Vega 2006; Carpenter and Rondi 2000; Magri 2009). In the same context, firm internationalisation and innovation often entails a strong increase of competitive pressure and failure risk (Giovannetti et al. 2013), and maturity and foreign market experience increase the chance of post-internationalisation survival (Autio et al. 2000; Carr et al. 2010). Finally, the regime of 'creative accumulation' (Schumpeter Mark II) that characterises the most competitive Italian industries (e.g. motor vehicles and non-electrical machinery)

Table 3 Correlation matrix $(n=30,670)$

\begin{tabular}{lcccccc}
\hline & Growth & Pat Green & Pat Nongreen & Age & Emp & Inv Tang Inv Intang \\
\hline Pat Green & 0.001 & & & & & \\
Pat Nongreen & -0.0249 & 0.2571 & & & & \\
Age & -0.1264 & 0.0095 & 0.1033 & & & \\
Emp & -0.1741 & 0.1811 & 0.3652 & 0.302 & & \\
Inv Tang & -0.0103 & 0.1586 & 0.2815 & 0.2115 & 0.7361 & 0.4613 \\
Inv Intang & 0.0078 & 0.144 & 0.3109 & 0.0644 & 0.5068 & 0.0579 \\
Herfindahl index & 0.0006 & 0.0542 & 0.0125 & -0.0197 & 0.0618 & 0.0316 \\
\hline
\end{tabular}


Table 4 Quantile regression with fixed effects: firm growth's determinants

\begin{tabular}{|c|c|c|c|c|c|}
\hline & q10 & $\mathrm{q} 25$ & $\mathrm{q} 50$ & $\mathrm{q} 75$ & q90 \\
\hline $\mathrm{Age}_{t-1}$ & $\begin{array}{l}0.098 * * * \\
(0.002)\end{array}$ & $\begin{array}{l}0.089 * * * \\
(0.001)\end{array}$ & $\begin{array}{l}0.081 * * * \\
(0.001)\end{array}$ & $\begin{array}{l}0.074 * * * \\
(0.001)\end{array}$ & $\begin{array}{l}0.061 * * * \\
(0.002)\end{array}$ \\
\hline Pat Green $_{t-1}$ & $\begin{array}{l}0.021 * * \\
(0.009)\end{array}$ & $\begin{array}{l}0.022 * * * \\
(0.002)\end{array}$ & $\begin{array}{l}0.021 * * * \\
(0.001)\end{array}$ & $\begin{array}{l}0.025 * * * \\
(0.003)\end{array}$ & $\begin{array}{l}0.023 * * * \\
(0.006)\end{array}$ \\
\hline Pat Nongreen $t-1$ & $\begin{array}{l}0.007 * * * \\
(0.002)\end{array}$ & $\begin{array}{l}0.013 * * * \\
(0.001)\end{array}$ & $\begin{array}{l}0.014 * * * \\
(0.000)\end{array}$ & $\begin{array}{l}0.015 * * * \\
(0.001)\end{array}$ & $\begin{array}{l}0.020 * * * \\
(0.002)\end{array}$ \\
\hline $\mathrm{Emp}_{t-1}$ & $\begin{array}{l}-0.424 * * * \\
(0.002)\end{array}$ & $\begin{array}{l}-0.437 * * * \\
(0.001)\end{array}$ & $\begin{array}{l}-0.447 * * * \\
(0.000)\end{array}$ & $\begin{array}{l}-0.458 * * * \\
(0.001)\end{array}$ & $\begin{array}{l}-0.473 * * * \\
(0.001)\end{array}$ \\
\hline Inv Intang ${ }_{t-1}$ & $\begin{array}{l}-0.001 \\
(0.001)\end{array}$ & $\begin{array}{l}0.002 * * * \\
(0.000)\end{array}$ & $\begin{array}{l}0.004 * * * \\
(0.000)\end{array}$ & $\begin{array}{l}0.006 * * * \\
(0.000)\end{array}$ & $\begin{array}{l}0.008 * * * \\
(0.001)\end{array}$ \\
\hline Inv $\operatorname{Tang}_{t-1}$ & $\begin{array}{l}0.016 * * * \\
(0.001)\end{array}$ & $\begin{array}{l}0.015 * * * \\
(0.001)\end{array}$ & $\begin{array}{l}0.016 * * * \\
(0.000)\end{array}$ & $\begin{array}{l}0.017 * * * \\
(0.000)\end{array}$ & $\begin{array}{l}0.021 * * * \\
(0.001)\end{array}$ \\
\hline Herfindahl index ${ }_{t}$ & $\begin{array}{l}-0.152 \\
(0.174)\end{array}$ & $\begin{array}{l}-0.044 \\
(0.073)\end{array}$ & $\begin{array}{l}0.016 * * * \\
(0.006)\end{array}$ & $\begin{array}{l}0.072 \\
(0.044)\end{array}$ & $\begin{array}{l}0.178 * * * \\
(0.060)\end{array}$ \\
\hline Constant & $\begin{array}{l}1.049 * * * \\
(0.007)\end{array}$ & $\begin{array}{l}1.184 * * * \\
(0.008)\end{array}$ & $\begin{array}{l}1.287 * * * \\
(0.004)\end{array}$ & $\begin{array}{l}1.374 * * * \\
(0.005)\end{array}$ & $\begin{array}{l}1.470 * * * \\
(0.010)\end{array}$ \\
\hline $\begin{array}{l}\text { Pat Green-Pat Nongreen } \\
\text { difference test }\end{array}$ & $\begin{array}{l}0.014 \\
(0.01)\end{array}$ & $\begin{array}{l}0.009 * * * \\
(0.002)\end{array}$ & $\begin{array}{l}0.007 * * * \\
(0.001)\end{array}$ & $\begin{array}{l}0.009 * * * \\
(0.003)\end{array}$ & $\begin{array}{l}0.004 \\
(0.006)\end{array}$ \\
\hline Test for intra-industry correlation & $14.860 * * *$ & $5.528 * * *$ & -0.147 & $10.893 * * *$ & $14.722 * * *$ \\
\hline Firm-year obs & & & 30,670 & & \\
\hline Firm obs & & & 5498 & & \\
\hline
\end{tabular}

Year dummy variables have been included in all of the models. Bootstrapped standard errors are reported in parentheses. They are based on 1000 replications of the data

$* p<0.10, * * p<0.05, * * * p<0.01$

(Malerba and Orsenigo 1995) could lend knowledge accumulation and innovation persistence experienced by mature firms a larger impact, also on the growth performance of sectoral systems of environmental innovation (Chassagnon and Haned 2015; Oltra and Saint Jean 2009).

We now come to the core of our analysis. As Table 4 shows, the positive and significant coefficients of both Pat Nongreen and Pat Green across the whole set of percentiles confirm the role of green technology as a driver of firm growth. This finding supports and extends the emerging evidence on the business environmental win-win situations enhanced by environmental practices. Indeed, as we expected, the increase of product value and the reduction of production costs they entail (Ambec and Lanoie 2008) actually seem to translate into higher growth.

A more relevant aspect to consider is the comparison between the coefficients of Pat Green and Pat Nongreen across the quantiles of the distribution. This comparison is crucial for assessing whether green technologies provide a growth premium with respect to non-green technologies or whether, instead, the effects of green and non-green patents are not different. By running appropriate statistical tests on the difference between the two coefficients (tests are reported in Table 4), we found that the difference between Pat Green and Pat Nongreen is not homogeneous across the quantiles. Specifically, it emerges that for the 25th, 50th and 75th percentiles, green technologies have a significantly larger effect (at a 99\% level of confidence) on growth than standard technologies, while for the 10th and the 90th percentiles, green and non-green patents have statistically similar effects on firm growth. In brief, the growth premium of green over non-green technologies is not unlimited and weakens when innovation efforts are pursued either to survive (struggling firms) or to remain among the growth 'superstars' (gazelles).

The picture becomes more nuanced when we introduce interaction terms to capture the moderating role of age (Table 5). While Pat Nongreen remains positive and significant, except for the 10th and 25th percentiles, Pat Green, per se, is not positive and becomes negative and significant for the 75th and 90th percentiles. However, 
Table 5 Quantile regression with fixed effects: firm growth's determinants - interaction effects

\begin{tabular}{|c|c|c|c|c|c|}
\hline & $\mathrm{q} 10$ & $\mathrm{q} 25$ & $\mathrm{q} 50$ & $\mathrm{q} 75$ & $\mathrm{q} 90$ \\
\hline $\mathrm{Age}_{t-1}$ & $\begin{array}{l}0.082 * * * \\
(0.018)\end{array}$ & $\begin{array}{l}0.097 * * * \\
(0.003)\end{array}$ & $\begin{array}{l}0.088 * * * \\
(0.001)\end{array}$ & $\begin{array}{l}0.081 * * * \\
(0.001)\end{array}$ & $\begin{array}{l}0.072 * * * \\
(0.001)\end{array}$ \\
\hline Pat Green $_{t-1}$ & $\begin{array}{l}-0.012 \\
(0.057)\end{array}$ & $\begin{array}{l}0.020 \\
(0.019)\end{array}$ & $\begin{array}{l}-0.002 \\
(0.009)\end{array}$ & $\begin{array}{l}-0.012 * * * \\
(0.003)\end{array}$ & $\begin{array}{l}-0.020^{* * *} \\
(0.010)\end{array}$ \\
\hline Pat Nongreen $t-1$ & $\begin{array}{l}0.026 \\
(0.041)\end{array}$ & $\begin{array}{l}0.010 \\
(0.015)\end{array}$ & $\begin{array}{l}0.023 * * * \\
(0.004)\end{array}$ & $\begin{array}{l}0.023 * * * \\
(0.003)\end{array}$ & $\begin{array}{l}0.020 * * * \\
(0.004)\end{array}$ \\
\hline Pat Green ${ }_{t-1} \mathrm{X} \mathrm{Age}_{t-1}$ & $\begin{array}{l}0.011 \\
(0.017)\end{array}$ & $\begin{array}{l}0.000 \\
(0.005)\end{array}$ & $\begin{array}{l}0.008 * * * \\
(0.003)\end{array}$ & $\begin{array}{l}0.011 * * * \\
(0.001)\end{array}$ & $\begin{array}{l}0.014 * * * \\
(0.003)\end{array}$ \\
\hline Pat Nongreen $_{t-1} \mathrm{X} \mathrm{Age}_{t-1}$ & $\begin{array}{l}-0.004 \\
(0.012)\end{array}$ & $\begin{array}{l}-0.001 \\
(0.005)\end{array}$ & $\begin{array}{l}-0.003 * * \\
(0.001)\end{array}$ & $\begin{array}{l}-0.003 * * * \\
(0.001)\end{array}$ & $\begin{array}{l}-0.002 \\
(0.001)\end{array}$ \\
\hline $\mathrm{Emp}_{t-1}$ & $\begin{array}{l}-0.455^{* * * *} \\
(0.020)\end{array}$ & $\begin{array}{l}-0.424 * * * \\
(0.002)\end{array}$ & $\begin{array}{l}-0.437 * * * \\
(0.001)\end{array}$ & $\begin{array}{l}-0.447 * * * \\
(0.000)\end{array}$ & $\begin{array}{l}-0.458 * * * \\
(0.001)\end{array}$ \\
\hline Inv Intang $g_{t-1}$ & $\begin{array}{l}0.005 * * * \\
(0.001)\end{array}$ & $\begin{array}{l}-0.001 \\
(0.001)\end{array}$ & $\begin{array}{l}0.002 * * * \\
(0.000)\end{array}$ & $\begin{array}{l}0.004 * * * \\
(0.000)\end{array}$ & $\begin{array}{l}0.006 * * * \\
(0.000)\end{array}$ \\
\hline Inv $\operatorname{Tang}_{t-1}$ & $\begin{array}{l}0.020 * * * \\
(0.002)\end{array}$ & $\begin{array}{l}0.016 * * * \\
(0.001)\end{array}$ & $\begin{array}{l}0.015 * * * \\
(0.001)\end{array}$ & $\begin{array}{l}0.016 * * * \\
(0.000)\end{array}$ & $\begin{array}{l}0.017 * * * \\
(0.000)\end{array}$ \\
\hline Herfindahl index ${ }_{t}$ & $\begin{array}{l}0.046 * * * \\
(0.011)\end{array}$ & $\begin{array}{l}-0.151 \\
(0.158)\end{array}$ & $\begin{array}{l}-0.043 \\
(0.075)\end{array}$ & $\begin{array}{l}0.019 * * * \\
(0.005)\end{array}$ & $\begin{array}{l}0.072 * \\
(0.042)\end{array}$ \\
\hline Constant & $\begin{array}{l}1.233 * * * \\
(0.062)\end{array}$ & $\begin{array}{l}1.074 * * * \\
(0.012)\end{array}$ & $\begin{array}{l}1.198 * * * \\
(0.008)\end{array}$ & $\begin{array}{l}1.295 * * * \\
(0.007)\end{array}$ & $\begin{array}{l}1.382 * * * \\
(0.006)\end{array}$ \\
\hline Test for intra-industry correlation & $15.142 * * *$ & $5.468 * * *$ & -0.102 & $10.685 * * *$ & $14.730 * * *$ \\
\hline Firm-year obs & & & 30,670 & & \\
\hline Firm obs & & & 5498 & & \\
\hline
\end{tabular}

Year dummy variables have been included in all of the models. Bootstrapped standard errors are reported in parentheses. They are based on 1000 replications of the data

$* p<0.10, * * p<0.05, * * * p<0.01$

the effect of Pat Green, as shown in Table 5, should be understood in relation to the age of the company, given the contribution of the interaction between Pat Green and Age, which is always positive and significant, except for the 10th and 25th percentiles.

In other words, we find an apparently exclusive capacity of older firms to translate eco-innovation into growth. This is the second important result of our analysis, which is possibly linked to the points of firm maturity and eco-innovations discussed in Section 2. First, as we said, older firms may be better equipped to evaluate the uncertainty/risk and the actual marketability of their eco-innovations, irrespective of their likely disadvantages in terms of organisational inertia and learning impediments (Majumdar 1997; Sorensen and Stuart 2000; Criscuolo et al. 2012). Second, owing to better access to finance (Schneider and Veugelers 2010), older firms can have a higher capacity to cope with the cost of eco-innovating (Gagliardi et al. 2016) and with the resources needed to engage in signalling, labelling and certification efforts, which are often required to extract value from investment in green innovations (Ambec and Lanoie 2008). Third, older firms might have greater pressures and incentives for renewing their older capital vintages in an eco-sustainable manner-for example in responding to a policy constraint (Ruth et al. 2004) also in light of their greater capacity to exploit internal economies of scale and external knowledge sourcing (Herriott et al. 1985; Levitt and March 1988; Ghisetti et al. 2015). Finally, the persistence of the learning and innovation patterns that characterises green technologies (Sàez-Martínez et al. 2016, Chassagnon and Haned 2015) can 'reserve' the growth impact to firms that are capable of reaping the benefits of their path dependence.

While favouring older firms, the implications of our results for entrepreneurial growth are quite discouraging. When attempting to pursue the heavily uncertain path of growth (e.g. Coad et al. 2013), young companies are able to obtain shortterm gains only from standard innovations, which 
do not target external benefits associated to environmental protection and are arguably less distant from the traditional industrial knowledge base (Ghisetti et al. 2015). Interestingly, these gains occur for the central quantiles of the distribution, as can be noticed from the negative and significant coefficients on the interaction term Pat Nongreen $\mathrm{X}$ Age in the 50th and 75th percentiles. For rapidly or slowly growing companies, age does not moderate the growth-driving effects of non-green technologies.

We further qualify the additional effect of green technologies compared to non-green technologies for the quantiles where the interaction between Pat Green and Age is significant (Table 5, percentiles 50th to 90th). For young firms (those with less than 5 years for the 50th and 75th percentiles of growth rate and below 10 years for the 90 th percentile), a stronger association can be determined between non-green technologies and firm growth vs. green technologies and growth. On the contrary, for more mature firms (i.e. those with more than 20 years for the 50th and 75 th percentiles of growth rate and above 30 years for the 90th percentile), green technologies exert a higher effect on firm growth compared to non-green technologies (Figure A3 in the Online Appendix provides a graphical representation). These quantile-specific effects further confirm the choice of a quantile approach as the most suitable to identifying the different effects of the interplay between green technology and age on firm growth.

\section{Conclusions}

In this paper, we examined the capacity of green technologies to sustain firm growth, building upon the idea that a firm's capacity to grow is closely linked to its ability to master technological knowledge and capture the value of the innovation (Mansfield 1962; Scherer 1965). While an extensive body of industrial organisation and innovation literature has addressed the growth impact of technology (e.g. Audretsch et al. 2014), only a few studies have examined the relationship between green technologies and firm growth. Our contribution is novel for two reasons. First, we assessed whether green technologies, compared to non-green technologies, affect the growth of firms with different growth paces (e.g. struggling or rapidly growing). Second, we considered whether green-based growth is affected by a firm's age.

We adopted a novel econometric approach, combining panel fixed effects with quantile regression estimations. We thus simultaneously controlled for unobserved heterogeneity (which is likely to affect firm growth) and for the heterogeneity of the growth process, along the distribution of growth rates.

Our analysis of a large sample of Italian firms between 2000 and 2008 confirms the vital role of green and non-green technologies in fostering firm growth, as measured by the growth of employment. Moreover, the results indicate a 'win-win' situation as green technologies exert superior effects on growth than non-green ones. The possibility to enter green markets, to decrease production costs because of greater resource efficiency (e.g. reduced material and energy use) and to reinvest the relative extra returns from eco-innovating can justify this result. However, our analysis shows that the superior effect of green technologies does not extend to the extreme percentiles of the growth rate distribution.

The second contribution of the paper pertains to the moderating effects of age: the green growth path is mainly taken by mature firms (age higher than 20 or 30 years), with the exception of the slow-growing ones. Hence, more mature companies seem to be better equipped to transform green technology into growth. Although further research is required, we contend that greater experience, fewer financial constraints and exemption from issues related to the liability of newness (e.g. Freeman et al. 1993) — a set of aspects that are particularly relevant in the Italian context-allow older firms to engage successfully in complex and uncertain technological projects, such as environmentally related ones. These results are partially balanced by the positive effects on young companies of non-green technologies, which trigger short-term firm growth (for the central quantiles), possibly because of their less complex and costly nature.

These results hold important implications both for management and for policy. Extracting value from green technology and transforming it into higher growth is not a 'one-size-fits-all' strategy. On the one hand, struggling firms might not find it viable to engage in more complex and costly green technological projects. On the other hand, for the elite group of fast-growing companies, a green orientation might not add to their portfolios of already outperforming and possibly unique - compared to their competitors-technological capabilities. As 
said, our results suggest that the process of green-led growth is a complex and costly one: only older companies are sufficiently broad shouldered to pursue a growth path based on environmental technology.

Building on our evidence, we also believe that our results have relevant implications for policy makers. If their short-run objective is to maximise the social impact of public resources in supporting the transition towards green forms of production, the main beneficiary group should be made of relatively established firms, rather than start-ups. This aspect should be considered when implementing policies favouring innovative start-ups (e.g. Mason and Brown 2013; European Commission 2014).

In conclusion, this is a first attempt at providing empirical evidence for the relation between firm growth and green technology. From a policy implications' perspective, future research should investigate the mechanisms that make growth particularly problematic for young companies. Further research should also go beyond patenting firms: patent data, although the most diffused source of information for defining continuous firm-level innovation variables (e.g. Gagliardi et al. 2016) does not capture all the innovations introduced by firms (Griliches 1990).

Acknowledgements Previous versions of this paper have been presented at the following: workshop "Born to be Green. The Economics and Management of Green Start-Ups", Southampton Business School (UK) 21-22 May 2015; 2016 Italian Economic Association Conference, Bocconi University of Milan (IT), 20-22 October 2016; 13th European Network on the Economics of the Firm (ENEF) Meeting, University of Turin (IT), 13-14 September, 2016; SPRU 50th Anniversary Conference, University of Sussex (UK), 7-9 September 2016; 2016 Conference of the Governance of a Complex World (GCW) "Innovation, Employment and the Environment", INGENIO (CSIS-UPV), Valencia (ES), 22-24 June 2016; 2016 DRUID Conference, Copenhagen Business School (DK) 13-15 June 2016. We are grateful to the discussants and participants of these conferences, as well as to two anonymous referees for their precious comments. We also acknowledge the help and suggestions of Giovanni Marin and Alex Coad on data and methods, respectively. Usual caveats apply.

Open Access This article is distributed under the terms of the Creative Commons Attribution 4.0 International License (http:// creativecommons.org/licenses/by/4.0/), which permits unrestricted use, distribution, and reproduction in any medium, provided you give appropriate credit to the original author(s) and the source, provide a link to the Creative Commons license, and indicate if changes were made.

\section{References}

Acs, Z., Audretsch, D. B. 2006. Handbook of entrepreneurship research: an interdisciplinary survey and introduction. Vol.1, Springer Science \& Business Media.

Ambec, S., \& Lanoie, P. (2008). Does it pay to be green? A systematic overview. Academy of Management Perspectives, 22(4), 45-62. https://doi.org/10.5465/AMP.2008.35590353.

Ambec, S., Cohen, M. A., Elgie, S., \& Lanoie, P. (2013). The Porter hypothesis at 20: can environmental regulation enhance innovation and competitiveness? Review of Environmental Economics and Policy, 7(1), 2-22.

Almus, M. (2002). What characterizes a fast-growing firm? Applied Economics, 34, 1497-1508.

Arundel, A., Kemp, R. 2009. Measuring eco-innovation. 2009017. UNU-MERIT Working Paper Series. Maastricht. https://search.oecd.org/greengrowth/consumptioninnovation/43960846.pdf.

Audretsch, D. B., Coad, A., \& Segarra, A. (2014). Firm growth and innovation. Small Business Economics. https://doi. org/10.1007/s11187-014-9560-x.

Audretsch, D. B., Santarelli, E., \& Vivarelli, M. (1999). Start-up size and industrial dynamics: some evidence from Italian manufacturing. International Journal of Industrial Organization, 17(7), 965-983.

Autio, E., Sapienza, H. J., \& Almeida, J. G. (2000). Effects of age at entry, knowledge intensity, and imitability on international growth. Academy of Management Journal, 43(5), 909-924. https://doi.org/10.2307/1556419.

Barba Navaretti, G., Castellani D., Pieri, F. 2014. Age and firm growth: evidence from three European countries. Small Business Economics, 1-15. doi:https://doi.org/10.1007 /s11187-014-9564-6.

Benfratello, L., Schiantarelli, F., \& Sembenelli, A. (2008). Banks and innovation: microeconometric evidence on Italian firms. Journal of Financial Economics, 90(2), 197-217.

Berrone, P., Fosfuri, A., Gelabert, L., \& Gomez-Mejia, L. R. (2013). Necessity as the mother of 'green' inventions: institutional pressures and environmental innovations. Strategic Management Journal, 34(8), 891-909. https://doi. org/10.1002/smj.2041.

Bird, L. A., Wüstenhagen, R., \& Aabakken, J. (2002). A review of international green power markets: recent experience, trends, and market drivers. Renewable and Sustainable Energy Reviews, 6, 513-536.

Bloom, N., \& Van Reenen, J. (2002). Patents, real options and firm performance. Economic Journal, 112(478). https://doi. org/10.1111/1468-0297.00022.

Blundell, R., Griffith, R., \& Van Reenen, J. (1995). Dynamic count data models of technological innovation. The Economic Journal, 105(429), 333. https://doi.org/10.2307/2235494.

Bottazzi, G., Coad, A., Jacoby, N., \& Secchi, A. (2011). Corporate growth and industrial dynamics: evidence from French manufacturing. Applied Economics, 43(1), 103-116. https://doi.org/10.1080/00036840802400454.

Bottazzi, G., \& Secchi, A. (2003). Why are distributions of firm growth rates tent-shaped? Economics Letters, 80(3), 415420. https://doi.org/10.1016/S0165-1765(03)00142-3. 
Bottazzi, G., \& Secchi, A. (2006). Explaining the distribution of firm growth rates. The Rand Journal of Economics, 37(2), 235256. https://doi.org/10.1111/j.1756-2171.2006.tb00014.x.

Buchinsky, M. (1998). Recent advances in quantile regression models: a practical guideline for empirical research. The Journal of Human Resources, 33(1), 88-126. https://doi. org/10.2307/146316.

Cainelli, G., De Marchi, V., \& Grandinetti, R. (2015). Does the development of environmental innovation require different resources? Evidence from Spanish manufacturing firms. Journal of Cleaner Production, 94(2015), 211-220.

Calvo, J. L. (2006). Testing Gibrat's law for small, young and innovating firms. Small Business Economics, 26, 117-123.

Canay, I. A. (2011). A simple approach to quantile regression for panel data. The Econometrics Journal, 14(3), 368-386. https://doi.org/10.1111/j.1368-423X.2011.00349.x.

Carpenter, R. E., \& Rondi, L. (2000). Italian corporate governance, investment, and finance. Empirica, 27(4), 365-388.

Carr, J. C., Haggard, K. S., Hmieleski, K. M., \& Zahra, S. A. (2010). A study of the moderating effects of firm age at internationalization on firm survival and short-term growth. Strategic Entrepreneurship Journal, 4(2), 183-192.

Carrillo-Hermosilla, J., Rio, P., \& Konnola, T. (2010). Diversity of eco-innovations: reflections from selected case studies. Journal of Cleaner Production, 18(10), 1073-1083.

Cefis, E. (2003). Is there persistence in innovative activities? International Journal of Industrial Organization, 21(4), 489-515.

Chassagnon, V., \& Haned, N. (2015). The relevance of innovation leadership for environmental benefits: a firm-level empirical analysis on French firms. Technological Forecasting and Social Change, 91, 194-207. https://doi.org/10.1016/j. techfore.2014.02.012.

Clarysse, B., Wright, M., \& Van de Velde, E. (2011). Entrepreneurial origin, technological knowledge, and the growth of spin-off companies. Journal of Management Studies, 48(6), 1420-1442. https://doi.org/10.1111/j.14676486.2010.00991.x.

Coad, A. 2009. The growth of firms: a survey of theories and empirical evidence. Edward Elgar Publishing.

Coad, A. (2010). Exploring the processes of firm growth: evidence from a vector auto-regression. Industrial and Corporate Change, 19(6), 1677-1703. https://doi.org/10.1093 /icc/dtq018.

Coad, A., and Holz, W. 2012. "Firm growth: empirical analysis. In Handbook on the economics and theory of the firm, edited by Michael Dietrich and Jackie Krafft. Edward Elgar Publishing.

Coad, A., Rao, R. 2006. Innovation and market value: a quantile regression analysis. Economics Bulletin 15 (1). doi: https://doi.org/10.1016/j.bbrc.2007.02.039.

Coad, A., \& Rao, R. (2008). Innovation and firm growth in hightech sectors: a quantile regression approach. Research Policy, 37(4), 633-648. https://doi.org/10.1016/j.respol.2008.01.003.

Coad, A., \& Rao, R. (2010). Firm growth and R\&D expenditure. Economics of Innovation and New Technology, 19(2), 127145. https://doi.org/10.1080/10438590802472531.

Coad, A., \& Rao, R. (2011). The firm-level employment effects of innovations in high-tech US manufacturing industries.
Journal of Evolutionary Economics, 21(2), 255-283. https://doi.org/10.1007/s00191-010-0209-x.

Coad, A., Segarra A., Teruel, M. 2013. Like milk or wine: does firm performance improve with age? Structural Change and Economic Dynamics 24. Elsevier B.V.: 173-89. doi: https://doi.org/10.1016/j.strueco.2012.07.002.

Coad, A., Segarra, A., \& Teruel, M. (2016). Innovation and firm growth: does firm age play a role? Research Policy, 45(2), 387-400. https://doi.org/10.1016/j. respol.2015.10.015.

Colombelli, A., Krafft, J., Quatraro, F. 2015. Eco-innovation and firm growth: do green gazelles run faster? Microeconometric evidence from a sample of European firms GREDEG Working Papers 2015-12, Groupe de REcherche en Droit, Economie, Gestion (GREDEG CNRS), University of Nice Sophia Antipolis.

Consoli, D., Marin, G., Marzucchi, A., \& Vona, F. (2016). Do green jobs differ from non-green jobs in terms of skills and human capital? Research Policy, 45(5), 1046-1060.

Criscuolo, P., Nicolaou, N., Salter, A. 2012. The elixir (or burden) of youth? Exploring differences in innovation between start-ups and established firms. Research Policy 41 (2). Elsevier B.V.: 319-33. doi:https://doi.org/10.1016/j.respol.2011.12.001.

D’Agostino, L. M. (2015). How MNEs respond to environmental regulation: integrating the Porter hypothesis and the pollution haven hypothesis. Economia Politica., 32(2), 245-269. https://doi.org/10.1007/s40888-015-0010-2.

Dean, T. J., \& McMullen, J. S. (2007). Toward a theory of sustainable entrepreneurship: reducing environmental degradation through entrepreneurial action. Journal of Business Venturing, 22(1), 50-76. https://doi.org/10.1016/j. jbusvent.2005.09.003.

Delmar, F., Davidsson, P., \& Gartner, W. (2003). Arriving at the high-growth firm. Journal of Business Venturing, 18, 189-216.

Denicolò, V. (2001). Growth with non-drastic innovations and the persistence of leadership. European Economic Review, 45(8), 1399-1141.

Distante, R., Petrella, I., Santoro, E. 2014. Size, age and the growth of firms: new evidence from quantile regressions. Fondazione Enrico Mattei Working Paper, Paper 970. Available at: http://services.bepress.com/feem/paper970

European Commission, 2014. European employment policy observatory review. Activating jobseekers through entrepreneurship: start-up incentives in Europe. Directorate-General for Employment, Social Affairs and Inclusion.

Evans, D. S. (1987). Test of alternative theories of firm growth. Journal of Political Economy, 95, 657-674.

Franco, C., Marzucchi, A. and Montresor, S. 2014.Absorptive capacity, proximity in cooperation and integration mechanisms. Empirical evidence from CIS data, Industry and Innovation, Vol. 21, n.4, pp. 332-357.

Freeman, J., Carroll, G. R., \& Hannan, M. T. (1993). The liability of newness: age dependence in organizational death rates. American Sociological Review, 48(5), 692. https://doi. org/10.2307/2094928.

Gagliardi, L., Marin, G., Miriello, C. 2016. The greener the better? Job creation effects of environmentally-friendly technological change. Industrial and Corporate Change, January. doi: https://doi.org/10.1093/icc/dtv054. 
Galvao, A. F. 2011. Quantile regression for dynamic panel data with fixed effects. Journal of Econometrics 164 (1). Elsevier B.V.: 142-57. doi:https://doi.org/10.1016/j.jeconom.2011.02.016.

Geroski, P. A., Van Reenen, J., \& Walters, C. F. (1997). How persistently do firms innovate? Research Policy, 26(1), 3348.

Geroski, P. A., Mata, J., \& Portugal, P. (2010). Founding conditions and the survival of new firms. Strategic Management Journal, 31(5), 510-529. https://doi.org/10.1002/smj.823.

Ghisetti, C., Marzucchi, A., \& Montresor, S. (2015). The open eco-innovation mode. An empirical investigation of eleven European countries. Research Policy, 44, 1080-1093. https://doi.org/10.1016/j.respol.2014.12.001.

Ghisetti, C., \& Rennings, K. (2014). Environmental innovations and profitability: how does it pay to be green? An empirical analysis on the German innovation survey. Journal of Cleaner Production, 75, 106-117.

Ghisetti, C., \& Quatraro, F. (2013). Beyond inducement in climate change: does environmental performance spur environmental technologies? A regional analysis of cross-sectoral differences. Ecological Economics, 96, 99-113.

Gibrat, R. (1931) Les inegualites economiques. Librairie du Receuil Sirey, Paris.

Gibrat, R. 2003. On economic inequalities. INTERNATIONAL LIBRARY OF CRITICAL WRITINGS IN ECONOMICS 158. EDWARD ELGAR PUBLISHING LTD: 497-514.

Giovannetti, G., Ricchiuti, G., \& Velucchi, M. (2013). Size, innovation and internationalization: a survival analysis of Italian firms. Applied Economics, 43(12), 1511-1520.

Grazzi, M., Jacoby, N., Treibich, T. 2015. Dynamics of investment and firm performance: comparative evidence from manufacturing industries Empirical Economics, in press.

Gregory, B. T., Rutherford, M. W., Oswald, S., \& Gardiner, L. (2005). An empirical investigation of the growth cycle theory of small firm financing. Journal of Small Business Management. https://doi.org/10.1111/j.1540-627X.2005.00143.x.

Griliches, Z. (1990). Patent statistics as economic indicators: a survey. Journal of Economic Literature, 28(4), 1661-1707.

Hall, B. H. (1987). The relationship between firm size and firm growth in the US manufacturing sector. The Journal of Industrial Economics. https://doi.org/10.2307/2098589.

Hall, B. H. (1993). The stock market's valuation of R\&D investment during the 1980's. The American Economic Review, 83(2), 259-264 http://www.jstor.org/stable/2117674?seq=1 \#page_scan_tab_contents.

Hall, B. H., Jaffe, A., \& Trajtenberg, M. (2005). Market value and patent citations. RAND Journal of Economics, 86, 24182427. https://doi.org/10.1007/s00216-009-2643-x.

Hall, B. H., Moncada-Paternò-Castello, P., Montresor, S., \& Vezzani, A. (2016). Financing constraints, R\&D investments and innovative performances: new empirical evidence at the firm level for Europe. Economics of Innovation and New Technology, 25(3), 183-196. https://doi.org/10.1080 /10438599.2015.1076194.

Hallegatte, S., Heal, G., Fay, M., Treguer, D. 2012. From growth to green growth - a framework, National Bureau of Economic Research NBER Working Paper No. 17841.

Haltiwanger, J., Jarmin, R., \& Miranda, J. (2013). Who creates jobs? Small versus large versus young. The Review of Economics and Statistics, 95(2), 347-361. https://doi. org/10.1162/REST_a_00288.
Hartarska, V., \& Gonzalez-Vega, C. (2006). What affects new and established firms' expansion? Evidence from small firms in Russia. Small Business Economics, 27(2-3), 195-206. https://doi.org/10.1007/s11187-006-0012-0.

Herriott, S. R., Levinthal, D. A., \& March, J. G. (1985). Learning from experience in organizations. The American Economic Review, 75(2), 298-302. https://doi.org/10.2307/1805614.

Hockerts, K., \& Wüstenhagen, R. (2010). Greening Goliaths versus emerging Davids theorizing about the role of incumbents and new entrants in sustainable entrepreneurship. Journal of Business Venturing, 25, 481-492.

Horbach, J., \& Rennings, K. (2013). Environmental innovation and employment dynamics in different technology fields - an analysis based on the German Community Innovation Survey 2009. Journal of Cleaner Production, 57(October), 158-165. https://doi.org/10.1016/j. jclepro.2013.05.034.

Horváthová, E. (2010). Does environmental performance affect financial performance? A meta-analysis. Ecological Economics, 70(1), 52-59. https://doi.org/10.1016/j. ecolecon.2010.04.004.

Kaniovski, S., \& Peneder, M. (2008). Determinants of firm survival: a duration analysis using the generalized gamma distribution. Empirica, 35(1), 41-58.

Kesidou, E., \& Demirel, P. (2012). On the drivers of eco-innovations: empirical evidence from the UK. Research Policy, 41(5), 862-870. https://doi.org/10.1016/j.respol.2012.01.005.

Koenker, R. (2004). Quantile regression for longitudinal data. Journal of Multivariate Analysis, 91(1), 74-89. https://doi. org/10.1016/j.jmva.2004.05.006.

Koenker, R., \& Hallock, K. F. (2001). Quantile regression. Journal of Economic Perspectives, 15(4), 143-156. https://doi. org/10.1257/jep.15.4.143.

Lawless, M. (2014). Age or size? Contributions to job creation. Small Business Economics, 42(4), 815-830.

Levitt, B., \& March, J. G. (1988). Organizational learning. Annual Review of Sociology, 14(1), 319-338. https://doi.org/10.1146 /annurev.so.14.080188.001535.

Licht, G., Peters, B. 2013. The impact of green innovation on employment growth in Europe. WWW for Europe Working Paper, n. 50. http://www.foreurope.eu/fileadmin/ ?documents/pdf/Workingpapers/WWWforEurope_WPS no050 MS53.pdf

Lotti, F., Santarelli, E., \& Vivarelli, M. (2009). Defending Gibrat's law as a long-run regularity. Small Business Economics, 32(1), 31-44. https://doi.org/10.1007/s11187-007-9071-0.

Lotti, F., Marin, G. 2013. Matching of PATSTAT applications to AIDA firms - discussion of the methodology and results. Occasional Papers (Questioni di Economia e Finanza) no. 166, Banca d'Italia.

Magri, S. (2009). The financing of small innovative firms: the Italian case. Economics of Innovation and New Technology., 18(2), 181-204.

Majumdar, S. K. (1997). The impact of size and age on firm-level performance: some evidence from India. Review of Industrial Organization, 12(2), 231-241. https://doi.org/10.1023 /A:1007766324749.

Malerba, F. (2005). Sectoral systems: how and why innovation differs across sectors. In J. Fagerberg, D. C. Mowery, \& R. R. Nelson (Eds.), The Oxford handbook of innovation (pp. 380 406). Oxford: Oxford University Press. 
Malerba, F. (1993). The national system of innovation: Italy. In R. Nelson (Ed.), National systems of innovations. Oxford: Oxford Univ. Press.

Malerba, F., \& Orsenigo, L. (1995). Schumpeterian patterns of innovation. Cambridge Journal of Economics, 19(1), 47-65.

Mansfield, E. (1962). Entry, Gibrat's law, innovation, and the growth of firms. American Economic Review, 52(5), 10231051. https://doi.org/10.1126/science.151.3712.867-a.

Marin, G. (2014). Do eco-innovations harm productivity growth through crowding out? Results of an extended CDM model. Research Policy, 43(2), 301-317.

Marin, G., Lotti, F. 2016. Productivity effects of eco-innovations using data on eco-patents, Industrial and Corporate Change, forthcoming.

Mason, C., \& Brown, R. (2013). Creating good public policy to support high-growth firms. Small Business Economics, 40, 211-225.

Mata, J., \& Portugal, P. (2002). The survival of new domestic and foreign-owned firms. Strategic Management Journal, 23(4), 323-343. https://doi.org/10.1002/smj.217.

Mazzanti, M., Rizzo, U. 2017. Diversely moving towards a green economy: techno-organisational decarbonisation trajectories and environmental policy in EU sectors Technological Forecasting and Social Change, 115,111-116. https://doi. org/10.1016/j.techfore.2016.09.026.

Misani, N., \& Pogutz, S. (2015). Unraveling the effects of environmental outcomes and processes on financial performance: a non-linear approach. Ecological Economics, 109, 150-160.

OECD. 2015. Patent search strategies for the identification of selected environment-related technologies (ENV-TEC). http://www.oecd.org/environment/consumptioninnovation/env-tech-search-strategies.pdf.

Oltra, V., \& Saint Jean, M. (2009). Sectoral systems of environmental innovation: an application to the French automotive industry. Technological Forecasting and Social Change, 7, 567-583. https://doi.org/10.1016/j.techfore.2008.03.025.

Parente, P. M., \& Santos Silva, J. (2016). Quantile regression with clustered data. Journal of Econometric Methods, 5(1), 1-15.

Parikka-Alhola, K. (2008). Promoting environmentally sound furniture by green public procurement. Ecological Economics, $68(1-$ 2), 472-485. https://doi.org/10.1016/j.ecolecon.2008.05.004.

Peters, B. (2009). Persistence of innovation: stylised facts and panel data evidence. The Journal of Technology Transfer, 34(2), 226-243.

Porter, M., \& Van der Linde, C. (1995). Toward a conception of the environment-competitiveness relationship. Journal of Economic Perspectives, 9(4), 97. https://doi.org/10.1257 /jep.9.4.97.

Raymond, W., Mohnen, P., Palm, F., \& Van Der Loeff, S. S. (2010). Persistence of innovation in Dutch manufacturing: is it spurious? The Review of Economics and Statistics, 92(3), 495-504.

Rennings, K., Ziegler, A., \& Zwick, T. (2004). The effect of environmental innovations on employment changes: an econometric analysis. Business Strategy and the Environment, 13(6), 374-387. https://doi.org/10.1002 /bse.424.

Rennings, K., \& Zwick, T. (2002). Employment impact of cleaner production on the firm level: empirical evidence from a survey in five European countries. International Journal of Innovation Management, 06(03), 319-342. https://doi. org/10.1142/S1363919602000604.

Ruth, M., Davidsdottir, B., \& Amato, A. (2004). Climate change policies and capital vintage effects: the cases of US pulp and paper, iron and steel, and ethylene. Journal of Environmental Management, 70(3), 235252.

Sàez-Martínez, F. J., Díaz-García, C., \& Gonzalez-Moreno, A. (2016). Firm technological trajectory as a driver of ecoinnovation in young small and medium-sized enterprises. Journal of Cleaner Production, 138, 28-37. https://doi. org/10.1016/j.jclepro.2016.04.108.

Scherer, F. M. (1965). Corporate inventive output, profits, and growth. Journal of Political Economy, 73(3), 290-297.

Schneider, C., \& Veugelers, R. (2010). On young highly innovative companies: why they matter and how (not) to policy support them. Industrial and Corporate Change, 19(4), 9691007. https://doi.org/10.1093/icc/dtp052.

Sorensen, J. B., \& Stuart, T. E. (2000). Aging obsolescence, and organizational innovation. Administrative Science Quarterly, 45, 81-112. https://doi.org/10.2307/2666980.

Stanley, M. H. R., Amaral, L. A. N., Buldyrev, S. V., Havlin, S., Leschhorn, H., Maass, P., Salinger, M. A., \& Stanley, H. E. (1996). Scaling behaviour in the growth of companies. Nature, 379, 804-806.

Stenzel, T., \& Frenzel, A. (2008). Regulating technological change. The strategic reactions of utility companies towards subsidy policies in the German, Spanish and UK electricity markets. Energy Policy, 36, 2645-2657.

Sutton, J. 1998. Gibrat's legacy. Journal of Economic Literature XXXV (March): 40-59.

Tsai, C. (2012). A research on selecting criteria for new green product development project: taking Taiwan consumer electronics products as an example. Journal of Cleaner Production, 25, 106-115. https://doi.org/10.1016/j. jclepro.2011.12.002.

Wooldridge, J. M. 2010. Econometric analysis of cross section and panel data. MIT Press. doi:https://doi.org/10.1515 /humr.2003.021. 